\title{
An assessment of in-field nutrient best management practices for agricultural crop systems with subsurface drainage
}

\author{
Andy Ward, Andrew Sharpley, Kayla Miller, Warren Dick, James Hoorman, John Fulton, and \\ Gregory A. LaBarge
}

and drainage to support agricultural production can be traced back thousands of years to the ancient civilization of Mesopotamia along the banks of the Euphrates and Tigris. A ubiquitous drainage need in the Great Lakes region and parts of the Mississippi Basin is subsurface drainage (generally called tile drainage) to remove excess water from fields and improve trafficability. However, it has long been recognized that tile drainage is a main contributor of nitratenitrogen $\left(\mathrm{NO}_{3}-\mathrm{N}\right)$ to water resources in these regions (Kladivko et al. 2004), and more recently studies have shown that tile drainage exports large amounts of phosphorus (P) (King et al. 2015). Nitrogen discharges from subsurface drainage systems are a common contributor to hypoxic zones in saltwater bodies, and dissolved $\mathrm{P}$ discharges are the primary cause of harmful algal blooms in freshwater bodies.

Here we review in-field best management practices (BMPs) to reduce nutrient losses from fields with subsurface drainage (USDA NRCS 2016). These USDA Natural Resources Conservation Service (NRCS) practice standards can vary from state to state to account for specific conditions that occur in a state.

Andy Ward is a professor in the Food, Agricultural and Biological Engineering Department, The Ohio State University, Columbus, Ohio. Andrew Sharpley is a professor in the Department of Crop, Soil, and Environmental Sciences, University of Arkansas, Fayetteville, Arkansas. Kayla Miller is the Knauss Marine Policy Fellow at the US Fish and Wildlife Services, Washington, DC. Warren Dick is emeritus professor in the School of Environment and Natural Resources, Ohio State University, Wooster, Ohio. James Hoorman is a soil health specialist for Michigan and Ohio, USDA Natural Resources Conservation Service, Findlay, Ohio. John Fulton is an associate professor in the Food, Agricultural, and Biological Engineering Department, The Ohio State University, Columbus, Ohio. Gregory A. LaBarge is an associate professor and field specialist, Agronomic Systems, The Ohio State University Extension, College of Food, Agriculture, and Environmental Sciences, London, Ohio.

\section{Figure 1}

A vegetated ditch in a field with senescing soybeans.

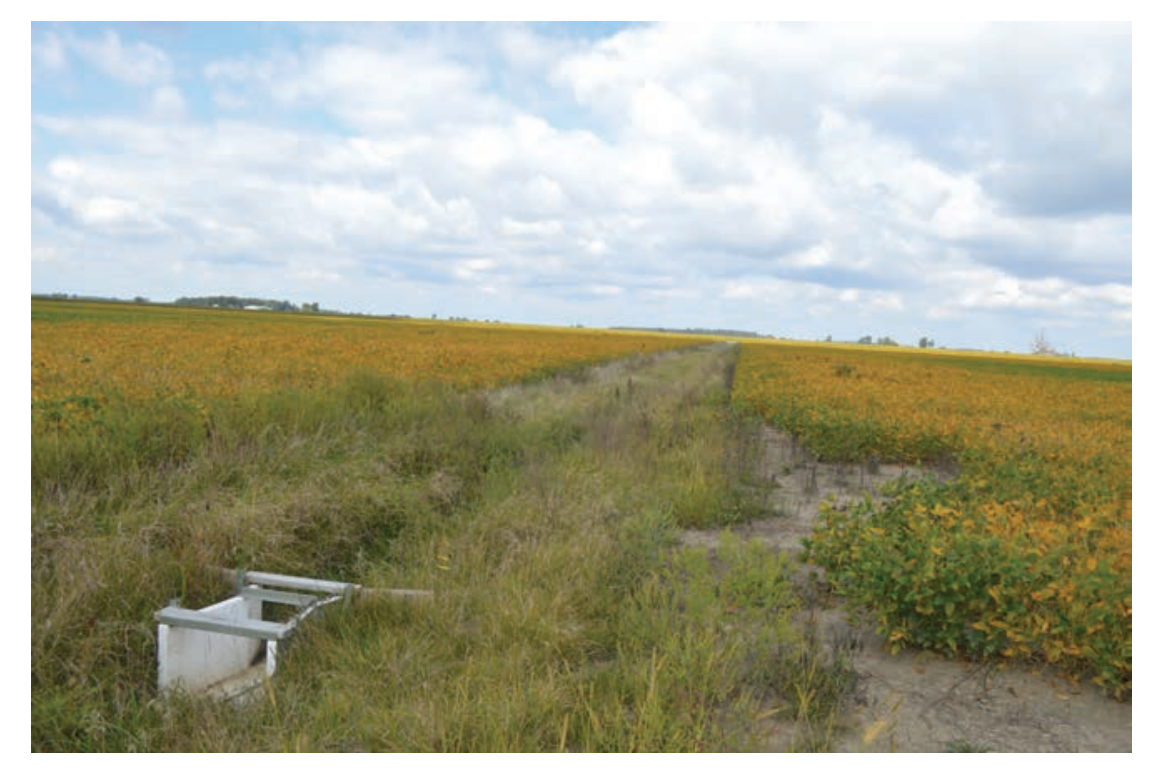

CONSERVATION PRACTICE STANDARD CODE 322: VEGETATED FIELD DITCHES Agricultural drainage ditches (figure 1) can mitigate $\mathrm{N}$ and $\mathrm{P}$ losses (Moore et al. 2010). Typically, the larger the ditch, the greater its nutrient mitigation and sediment retention capabilities due to an increased volume of water exposure to vegetation in larger ditches (Bouldin et al. 2004). Conversely, both Moore et al. (2010) and Shipitalo et al. (2010) found that there was no significant difference between the nutrient mitigation abilities of vegetated and unvegetated ditches. Here, a reduction in flow rate of ditches can aid sediment and associated nutrient deposition and chemical and biological uptake of $\mathrm{N}$ and $\mathrm{P}$ from ditch water.

A consideration for ditch-nutrient reduction efficiency is that ditches are designed to rapidly remove water from the landscape to allow for farming operations. However, this has exacerbated nutrient discharge and reduced nutrient retention capabilities. Twostage ditches (Powell et al. 2007; Roley et al. 2012), and in some cases an increase in the meandering of beyond-the-field ditch systems, have possibilities to enhance nutrient and sediment retention capacity.

\section{CONSERVATION PRACTICE STANDARD CODES 329, 345, 346: TILLAGE PRACTICES}

Conservation tillage practices, including reduced tillage and no-till (figure 2), leave more crop residue on the soil surface after planting and reduce root zone disturbance, resulting in reduced erosion and improved soil tilth. Water infiltration and structure is improved by preservation of natural channels formed by cracks, fissures, and biopores. In a long-term study in Ohio on two different soils, Kumar et al. (2012a) found that infiltration rates were at least 1.9 to 4.2 times greater under no-till when compared to those under minimum tillage and conventional moldboard plowing to $25 \mathrm{~cm}$ (10 in) followed by secondary tillage to $10 \mathrm{~cm}$ (4 in). Reduced-till was comprised of chisel plowing, without soil inversion, to $25 \mathrm{~cm}$ followed by cultivation to $10 \mathrm{~cm}$ before planting. They also found that soils in the no-till system had higher soil organic carbon (C), improved or maintained soil tilth, enhanced aggregate stability, and higher available water content (Kumar et al. 2012b).

A consequence of preferential flow paths is the channeling of surface water to subsurface 


\section{Figure 2}

Soybeans planted into no-till corn. Photo courtesy of Randall Reeder.

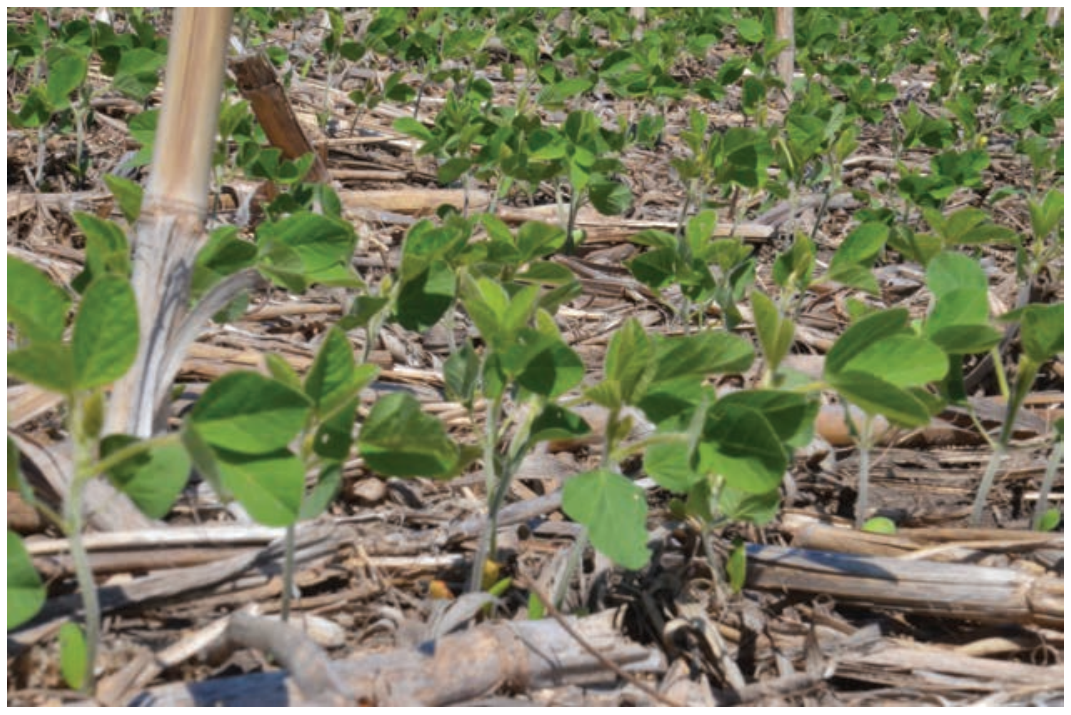

drainage, providing a direct linkage between the soil surface and tile drains, which promote P movement (King et al. 2015). Over an eight year watershed study, $\mathrm{P}$ transported in tile drains represented less than $2 \%$ of typical application rates in this watershed, but greater than $90 \%$ of all measured concentrations exceeded recommended levels $\left(0.03 \mathrm{mg} \mathrm{L}^{-1}\right)$ for minimizing harmful algal blooms and nuisance algae (King et al. 2015). When associated with higher soil test P levels at the soil surface (or surface applications of nutrient), water flow through preferential paths could result in increased dissolved $\mathrm{P}$ levels through tiles (Jarvie et al. 2017).

In Oklahoma, following conversion of two conventionally tilled watersheds to no-till wheat (Triticum aestivum L.), erosion and total $\mathrm{P}$ loss in runoff declined 95\% and $70 \%$, respectively (Sharpley and Smith 1994). However, both dissolved P loss in runoff, as well as $\mathrm{NO}_{3}-\mathrm{N}$ in groundwater, increased following the conversion to no-till wheat (Sharpley and Smith 1994). In conservation tillage systems, alternatives to surface placement of nutrients can have crop and water quality benefits. King et al. (2015) reported that tillage implements that impose minimal disturbance to the soil profile but place fertilizer below the surface have been found to be beneficial to water quality. Banded placement of fertilizer can also be beneficial in crop production (Randall and Hoeft 1998). To move away from surface applications of nutrients, practitioners of no-till systems have the opportunity to deliver nutrients through the planters, with high-speed equipment that minimally disturbs the soil surface, or use vertical tillage systems. In reduced tillage systems, the timing of fertilizer application prior to tillage or implementation of strip-tillage with fertilizer placement may offer improvements to tile losses of P. However, Hoorman and Shipatalo (2006), in a study of 98 animal waste spill records and fish kills in Ohio, determined that most occurred in areas with tile drainage and the most common contributing factor was application to saturated soils or rain after land application. They also noted that, while incorporation of liquid manure might reduce the potential for nutrient movement to tile drains in soil macropores, violations occurred even when wastes were applied to tilled soil.

\section{CONSERVATION PRACTICE STANDARD CODE 333: SOIL AMENDMENTS}

There has been a recent focus on the potential of soil amendments, such as alum sludge, steel slag, and fluidized gas desulfurization (FGD) gypsum to reduce the export of dissolved P from fields (Bryant et al. 2012). Application of gypsum can also promote flocculation of soils, which promotes the formation and stabilization of soil structure. This increases water infiltration, thereby decreasing soil erosion and nutrient runoff potential.A useful account of FGD gypsum applications in agricultural systems is provided in a series of manuscripts specific to this topic (Watts and Dick 2014).

In the midwestern United States, King et al. (2016) reported that FGD gypsum applied twice at a rate of $2.24 \mathrm{Mg} \mathrm{ha}^{-1}$ (1 tn $\left.\mathrm{ac}^{-1}\right)$, significantly decreased event mean dissolved and total $\mathrm{P}$ concentrations in the tile drainage after the first application of FGD gypsum. After the second application, significant reductions in dissolved P (36\%) and total P (38\%) in surface runoff and tile discharge combined were measured.

\section{CONSERVATION PRACTICE STANDARD} CODE 340: COVER CROPS

Cover crops (figure 3) protect the soil from erosion, improve soil tilth, and promote a healthy soil by increasing the number and species of beneficial microorganisms to compete with harmful species (Islam and Reeder 2014). Further, increased crop residue and soil $\mathrm{C}$ at the soil surface may increase soil infiltration and soil water holding capacity (Islam and Reeder 2014). As a result, cover crops have been shown to reduce $\mathrm{NO}_{3}-\mathrm{N}$ losses 13\% to 94\% (Strock et al. 2004; Kaspar et al. 2012). Cover crops may be grown to increase $\mathrm{C}$ sequestration and to increase soil $\mathrm{N}$ and $\mathrm{P}$ nutrient retention in a stable organic form that is plant available. Cover crops protect the soil by reducing the erosive energy of water and wind, conserving soil resources, and protecting water resources (Hoorman 2008; Islam and Reeder 2014).

The newly created USDA NRCS Soil Health Division promotes four major principles to improve water quality and improve soil health. These principles include (1) disturbing the soil less or as little as possible, (2) increasing soil biota and plant diversity to keep nutrients and water recycling efficiently, (3) keeping a living root growing throughout the year to increase nutrient recycling and the uptake of $\mathrm{N}$ and $\mathrm{P}$ during dormant periods (typically winter months), and (4) keeping the soil covered as much as possible with live plants to reduce soil and wind erosion and to lessen raindrop impact on the soil surface (USDA NRCS 2017). These soil health principles decrease problems associated with excess tillage (soil compaction, poor soil structure, reduced 


\section{Figure 3}

Corn following Austrian winter pea cover crop. Photo courtesy of Randall Reeder.

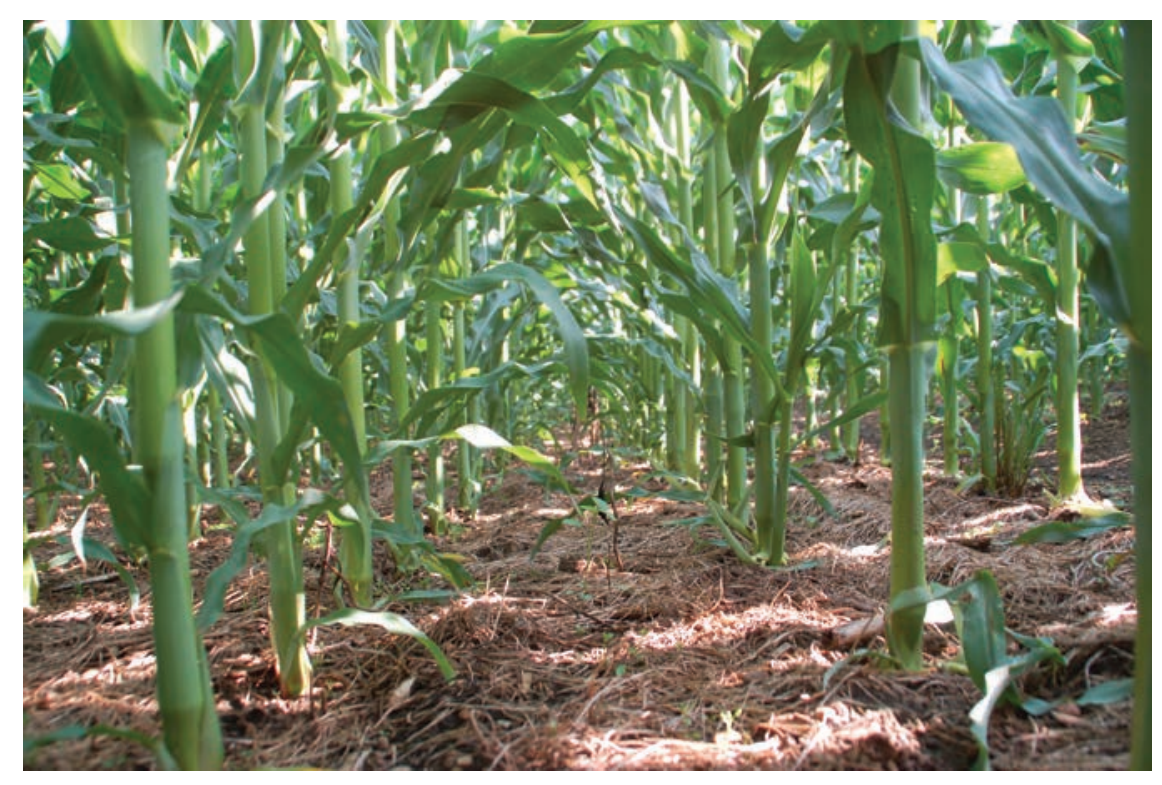

water infiltration, and excessive nutrient runoff), while increasing soil productivity, diversity, and resiliency.

While there are many benefits to cover crops, they add complexity to farming practices, require additional time and energy inputs, have the potential to introduce unwanted plants and pests into a field, and may have to be killed prior to planting of the cash crop. Planting a diversity of cover crop species and promoting beneficial micro- and macroorganisms may overcome many of these problems. Killing a crop may release N and $\mathrm{P}$ to drainage water, and this is especially critical if killing is done before or during the rainy season. To minimize problems with this "ecological farming" system, farmers need additional education on soil ecology and soil biology to promote a more natural farming system that mimics Mother Nature.

\section{CONSERVATION PRACTICE STANDARD CODES 393 AND 412: VEGETATED FILTER STRIPS AND GRASSED WATERWAYS}

Generally, grassed waterways (figure 4) are established on areas with up to $5 \%$ slope due to their primary purpose of stabilizing soil from erosion in natural drainage ways. However, grassed waterways have begun to appear in areas that are relatively flat with clayey soils and poor drainage abilities. Areas that combine both subsurface drainage and low over flattened regions with tile drainage (Noij et al. 2013). However, some research has indicated that vegetation might increase dissolved $\mathrm{P}$ concentrations during high flow events (Smith et al. 2015a). This release can also be exacerbated after freeze-thawing cycles that can rupture vegetative cells and release $\mathrm{N}$ and $\mathrm{P}$ (Bechmann et al. 2005).

\section{CONSERVATION PRACTICE STANDARD CODE 606: SUBSURFACE DRAINAGE SYSTEMS}

Subsurface drainage (figure 5) removes excess water from a soil profile by ditching or installation of buried "tile" constructed of clay; concrete; or perforated, corrugated polyethylene pipe. Conventional free-drainage systems are passively managed so that the shallow root-zone water table is effectively lowered to the depth of the drainage system outlet. This level of management permits farming under conditions where soils have poor natural drainage and are sufficient to satisfy agricultural production goals. However, tile drainage systems are one of the primary sources of $\mathrm{NO}_{3}-\mathrm{N}$ entering surface water and have been associated with the delivery of sediment, $\mathrm{P}$, and dissolved $\mathrm{P}$, pesticides, and coliform bacteria. Some research has shown that biofilters or slags might be used at the end of tiles to reduce $\mathrm{N}$ and $\mathrm{P}$ discharge (McDowell et al. 2008). Also, controlled

\section{Figure 4}

A grassed waterway between a corn and soybean field.

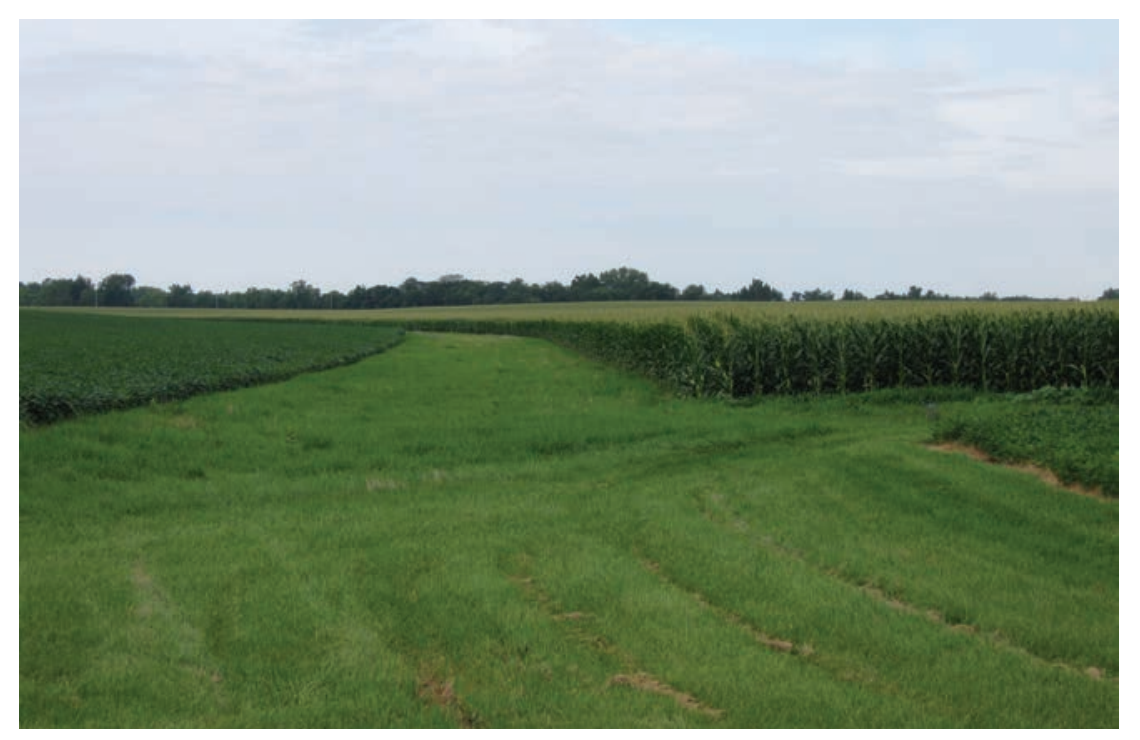




\section{Figure 5}

Fields with subsurface drainage with a $12 \mathrm{~m}$ spacing. The lighter color stripes illustrate drier soil above the drains (Google Earth Image USDA Farm Service Agency. December 31, 2009).

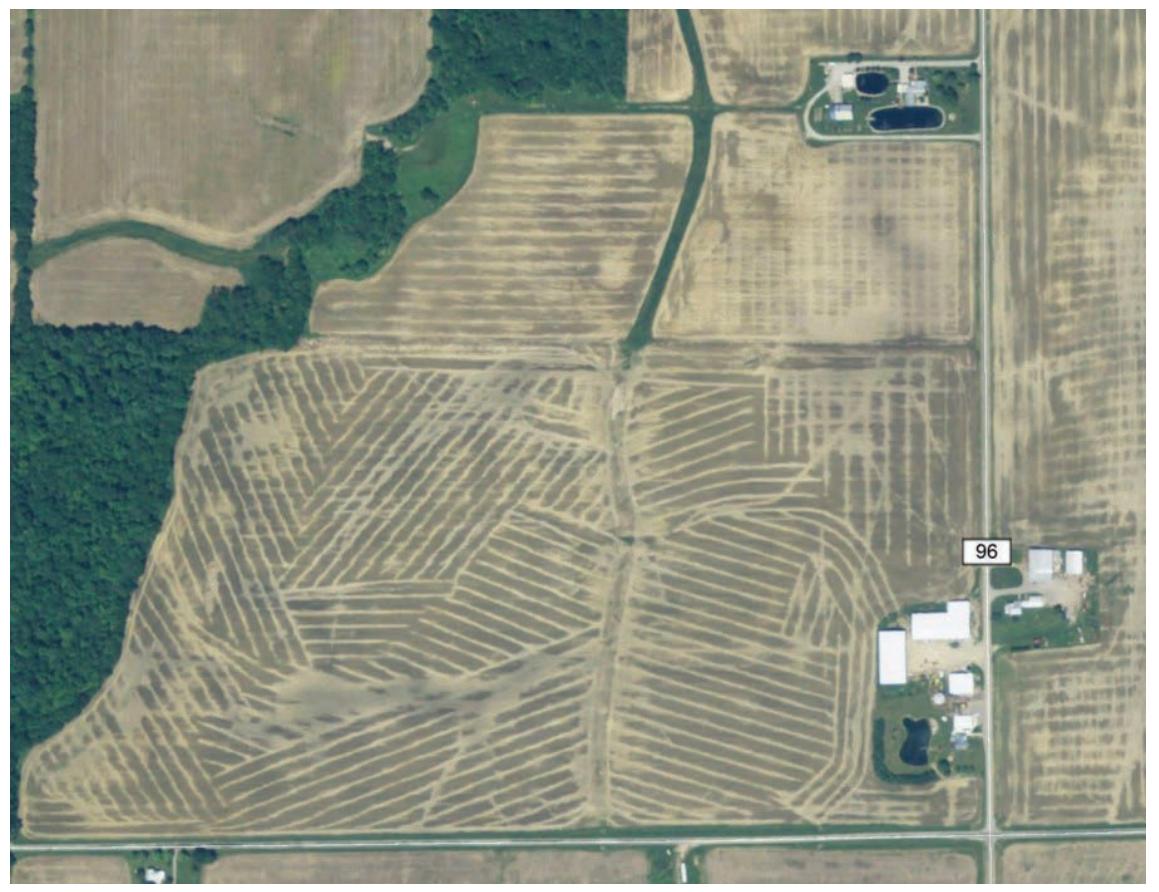

drainage of tiles can decrease water discharge during times when receiving waters might be more sensitive to receiving nutrients and retain water in the soil profile when dry soils may otherwise limit crop growth.

\section{CONSERVATION PRACTICE STANDARD}

\section{CODE 620: BLIND INLETS}

Blind inlets are structures that are engineered to decrease the amount of sediment and nutrients in field runoff. Blind inlets provide a direct connection from surface water to a tile drainage system (Feyereisen et al. 2015). NRCS engineers established the practice of lining the pit with a geotextile to extend sustainability and longevity of the blind inlet.

Blind inlets have been studied extensively in Indiana and Minnesota, where Smith and Livingston (2013) found that replacing two tile risers with blind inlets resulted in 68\% and $65 \%$ reductions in dissolved and total $\mathrm{P}$ loss, respectively. On the same field, Smith et al. (2015b) calculated a significant decrease in median flow-weighted mean dissolved $\mathrm{P}$ surface runoff concentration but no significant difference in median flow-weighted mean total P surface runoff when comparing the blind inlets to the regular tile risers. In Minnesota, Feyereisen et al. (2015) monitored 24 open inlets converted to gravel inlets on an alfalfa (Medicago sativa L.) crop rotation and concluded gravel inlets are able to reduce total suspended solids and dissolved P.

\section{OTHER IN-FIELD MANAGEMENT PRACTICES}

Strategies to reduce nutrient inputs and improve the efficiencies of nutrient use in production systems have perhaps the greatest potential to reduce high exports of nutrients to water resources. In the United States, the "4R" nutrient stewardship approach was developed by the fertilizer industry to provide a framework to achieve various goals, such as increased production, increased profitability, enhanced environmental protection, and improved sustainability (Christianson and Harmel 2015). The 4R approach advocates using the right fertilizer source, at the right rate, at the right time, and in the right place. It requires the implementation of practices that optimize the efficiency of fertilizer use. Difficulties with the approach are inadequate knowledge and tools to identify the best combination of field specific practices that will achieve production and profitability goals while reducing nutrient losses to levels that do not impair receiving water resources. A difficulty with cropping system practices is making or adjusting the management of inputs site-specifically based on actual weather and field conditions over the growing season. The complexity of the problem is discussed in a quantitative analysis by Christianson and Harmel (2015) of about 1,000 site-years of tile drainage $\mathrm{N}$ load data. They found that there was not a significant statistical difference in tile drainage exports of $\mathrm{N}$ between $\mathrm{N}$ application timing or application method.

Consistent with the 4Rs approach, precision agriculture and variable-rate applications of $\mathrm{N}$ and $\mathrm{P}$ (NRCS Conservation Practice Standard Code 590) have a potential to reduce exports of $\mathrm{N}$ and $\mathrm{P}$ from agricultural production systems. However, much of the focus of these technologies has been on improving yields while reducing inputs, but a lack of data on water quality benefits persists - particularly in fields with tile drainage. Precision agriculture technologies have afforded the ability to improve operation efficiency and timeliness especially related to nutrient management. Price (2011) estimated close to $10 \%$ reduced overlap with the use of GPS-based guidance technology. Automatic section control on application equipment has provided an average of $4.3 \%$ reduction of overlap of inputs (Runge et al. 2014), but in some fields the reduction can be as high as $30 \%$ depending on size and shape (Luck et al. 2011). Site-specific management of nutrients has the ability to improve fertilizer use efficiency while improving yields and reducing loss to the environment (Khosla et al. 2002). Most recently, efforts have focused on site-specific conservation management (e.g. precision conservation) that lend well to addressing the spatial and temporal variability of erosion and soil productivity (Delgado et al. 2011).

A practice that straddles being an infield and edge-of-field practice is drainage water management (NRCS Conservation Practice Standard Code 554)—often called controlled drainage. The purpose 
of the practice is to reduce tile drainage during times of the year when drainage requirements are reduced (Skaggs et al. 2012a). Ross et al. (2016) in a review of the literature determined that on average drainage water management reduced exports of $\mathrm{NO}_{3}-\mathrm{N}$ by $48 \%$, total $\mathrm{P}$ by $55 \%$, and dissolved reactive $\mathrm{P}$ by $57 \%$. A disadvantage of drainage water management is that it might impact the establishment of a cover crop and without care can adversely impact field operations prior to planting at the beginning of the growing season.

\section{MODELING NUTRIENT TRANSPORT VIA DRAINAGE SYSTEMS}

The most widely tested and used simulation model to account for nutrient transport from poorly drained fields is DRAINMOD (Skaggs et al. 2012b). There are a plethora of simulation models, such as the Soil and Water Assessment Tool (SWAT) (Green et al. 2006) and Spatially Referenced Regressions on Watershed attributes model (SPARROW) (McLellan et al. 2015), that make water quality estimations at watershed scales. For example, Kalcic et al. (2015b) used SWAT to evaluate notill, cereal rye (Secale cereale L.) cover crops, filter strips, grassed waterways, created wetlands, and restored prairie habitats in two west-central Indiana watersheds with tile drainage. Using spatial optimization techniques, they demonstrated a potential to reduce total pollutant loads by about $60 \%$. McLellan et al. (2015), in a study that used SPARROW in the Upper MississippiOhio River basin concluded that efforts to reduce $\mathrm{N}$ exports would benefit by (1) expanding their focus to include activities that restore and enhance nutrient processing in these highly altered landscapes; and (2) targeting specific types of BMPs to watersheds where they will be most valuable. Other models include the Agricultural Policy/Environmental eXtender (APEX) model that simulates a wide array of management practices, cropping systems, and other land uses for whole farms and small watersheds (Gassman et al. 2010).

\section{ADOPTION PERSPECTIVES}

We have refrained from attempting to document publications on in-field costs and benefits because they are site-specific and unlikely to be widely transferable. However, farmers who are more likely to adopt BMPs are generally one or a combination of the following: the landowner, young, more educated, already partaking in one or more BMPs, or hold leadership roles within the local agricultural community (Prokopy et al. 2008; Wilson et al. 2014). Kalcic et al. (2015a) investigated farmers' perceptions of conservation benefits by interviewing 14 farmers from Indiana. They found that farmers focused their conservation efforts on practices that retained or improved soil health, and increased crop yields. Few farmers considered water quality and nutrient runoff in making management decisions. In another study of the adoption of BMPs influencing tile drainage, Smith and Livingston (2013) reported that farmers preferred blind inlets over tile risers, because they are able to drive equipment across the surface of the inlet once backfilled.

\section{CONCLUSIONS}

Important issues for practice use are (1) where different BMPs should be applied, (2) the availability of tools to assist producers in implementing BMPs, (3) how to best bundle different BMPs together, and (4) the transferability of research knowledge to commercial farms. The answers to these questions often cannot be found in peerreviewed literature but in BMP guidance materials; reports and fact sheets; and at the agency, university, and stakeholder websites.

A common problem is an inadequate consideration of the hydrology of the system. This aspect is an important deficiency as dissolved nutrient exports are largely a function of hydrology. Adequately accounting for the hydrology of fields with tile drainage systems remains a challenge as these fields often exhibit macropores, such as cracks, that cause upwards wetting from an impeding layer below the drains as well as wetting downwards, through the soil matrix from the ground surface.

Each BMP discussed in this paper has advantages and disadvantages with regard to mitigating $\mathrm{N}, \mathrm{P}$, and sediment loading and improving water quality in surface waters across the world. Optimum BMP conditions and collaboration between stakeholders (government and university agencies and farmers) about BMP implementation would ensure the highest level of success for both agronomic productivity and nutrient and sediment mitigation. Of in-the-field, edge-of-field, and beyondthe-field BMPs, in-the-field practices are the most likely to produce visible shortterm agronomic benefits for the individual farmer. Due to this, agronomic benefits should be emphasized when presenting in-field BMPs to potential adopters.

\section{ACKNOWLEDGEMENTS}

The paper concept and authorship of the manuscript are associated with a Healthy Soils for Healthy Waters Initiative that was funded by a USDA National Institute of Food and Agriculture grant. Partial support for the manuscript development was from the US Environmental Protection Agency's Great Lakes Restoration Initiative. The views expressed in this manuscript are solely those of the authors and do not reflect those of the funding agencies or any other entities.

\section{REFERENCES}

Bechmann, M., P.J.A. Kleinman, A.N. Sharpley, and L.S. Saporito. 2005. Freeze-thaw effects on phosphorus loss in runoff from manured and catch cropped soils. Journal of Environmental Quality 34:2301-2309.

Bouldin, J.L., J.L. Farris, M.T. Moore, and C.M Cooper. 2004. Vegetative and structural characteristics of the agricultural drainages in the Mississippi Delta landscapes. Environmental Pollution 132:403-411.

Bryant, R.B., A.R. Buda, P.J. Kleinman, C.D. Church, L.S. Saporito, G.J. Folmar, S. Bose, and A.L. Allen. 2012. Using flue gas desulfurization gypsum to remove dissolved phosphorus from agricultural drainage waters. Journal of Environmental Quality 41:664-671.

Christianson, L.E., and R.D. Harmel. 2015. 4R Water Quality: An Assessment and synthesis of forty years of drainage nitrogen losses. Journal of Environmental Quality 44:1852-1860.

Delgado, J.A., R. Khosla, and T. Mueller. 2011. Recent advances in precision (target) conservation. Journal of Soil and Water Conservation 66(6):167A-170A, doi:10.2489/jswc.66.6.167A.

Feyereisen, G.W., W. Francesconi, D.R. Smith, S.K. Papiernik, E.S. Krueger, and C.D. Wente. 2015. Effect of replacing surface inlets with blind or gravel inlets on sediment and phosphorus subsurface drainage losses. Journal of Environmental Quality 44:594-604. 
Gassman, P.W., J.R. Williams, X. Wang, A. Saleh, E. Osei, L.M. Hauck, R.C. Izaurralde, and J.D. Flowers. 2010. The agricultural policy/environmental extender (APEX) model: An emerging tool for landscape and watershed environmental analyses. Transactions of the American Society of Agricultural and Biological Engineers 53:711-740.

Green, C.H., M.D. Tomer, M. Di Luzio, and J.G. Arnold. 2006. Hydrologic evaluation of the soil and water assessment tool for a large tile-drained watershed in Iowa. Transactions of the American Society of Agricultural and Biological Engineers 49:413-422.

Hoorman,J.J.2008. Using cover crops to improve soil and water. Ohio State University Extension Fact Sheet. Columbus, OH: Ohio State University Extension. http://www.mccc.msu.edu/states/Ohio/OH_ CoverCrops_to_Improve_Soi\&Water_Quality.pdf.

Hoorman, J.J., and M.J. Shipitalo. 2006. Subsurface drainage and liquid manure. Journal of Soil and Water Conservation 61(3):94A-97A.

Islam, R., and R. Reeder. 2014. No-till and conservation agriculture in the United States: An example from the David Brandt farm, Caroll, Ohio. International Soil and Water Conservation Research 2:97-107.

Jarvie, H.P., L.T. Johnson, A.N. Sharpley, D.R. Smith, D.B. Baker, T.W. Bruulsema, and R. Confesor. 2017. Increased soluble phosphorus loads to Lake Erie: Unintended consequences of conservation practices? Journal of Environmental Quality 46(1):123-132.

Kalcic, M., J. Frankenberger, and I. Chaubey. 2015b. Spatial optimization of six conservation practices using SWAT in tile-drained agricultural watersheds. Journal of the American Water Resources Association 51(4):956-972.

Kalcic, M., J. Frankenberger, I. Chaubey, L. Prokopy, and L. Bowling. 2015a. Adaptive targeting: Engaging farmers to improve targeting and adoption of agricultural conservation practices. Journal of the American Water Resources Association 51:973-991.

Kaspar, T.C., D.B. Jaynes, T.B. Parkin, T.B. Moorman, and J.W. Singer. 2012. Effectiveness of oats and rye cover crops in reducing nitrate losses in drainage water. Agricultural Water Management 110:25-33.

Khosla, R., K. Fleming, J.A. Delgado, T.M. Shaver, and D.G.Westfall. 2002. Use of site-specific management zones to improve nitrogen management for precision agriculture. Journal of Soil and Water Conservation 57(6):513-518.

King, K.W., M.R. Williams, W.A. Dick, and G.A. LaBarge. 2016. Decreasing phosphorus loss in tile-drained landscapes using flue gas desulfurization gypsum. Journal of Environmental Quality 45:1722-1730.

King, K.W., M.R. Williams, and N.R. Fausey. 2015. Contributions of systematic tile drainage to watershed scale phosphorus transport. Journal of Environmental Quality 44:486-494.

Kladivko, E.J., J.R. Frankenberger, D.B. Jaynes, D.W. Meek, B.J. Jenkinson, and N.R. Fausey. 2004. Nitrate leaching to subsurface drains as affected by drain spacing and changes in crop production system. Journal of Environmental Quality 33:1803-1813.
Kumar, S., A. Kadono, R. Lal, and W. Dick. 2012a. Long-term no-till impacts on organic carbon and properties of two contrasting soils and corn yields in Ohio. Soil Science Society of America Journal 76:1798-1809.

Kumar, S., A. Kadono, R. Lal, and W. Dick. 2012b. Long-term tillage and crop rotations for 47-49 years influences hydrological properties of two Soils in Ohio. Soil Science Society of America Journal 76:2195-2207.

Luck, J.D., R.S. Zandonadi, and S.A. Shearer. 2011.A case study to evaluate field shape factors for estimating overlap errors with manual and automatic section control. Transactions of the American Society of Agricultural and Biological Engineers 54(4):1237-1243.

McDowell, R.W., A.N. Sharpley, and W. Bourke. 2008. Treatment of drainage water with industrial by-products to prevent phosphorus loss from tiledrained land. Journal of Environmental Quality 37:1575-1582.

McLellan, E., D. Robertson, K. Schilling, M. Tomer, J. Kostel, D. Smith, and K. King. 2015. Reducing nitrogen export from the Corn Belt to the Gulf of Mexico: Agricultural strategies for remediating hypoxia. Journal of the American Water Resources Association 51(1):263-289.

Moore, M.T., R. Kröger, M.A. Locke, R.F. Cullum, R.W. Steinreide, S. Testa, R.E. Lizotte, C.T. Bryant, and C.M. Cooper. 2010. Nutrient mitigation capacity in Mississippi Delta, USA drainage ditches. Environmental Pollution 158:175-184.

Noij, I., M. Heinen, H. Heesmans, J. Thissen, and P. Groenendijk. 2013. Effectiveness of buffer strips without added fertilizer to reduce phosphorus loads from flat fields to surface waters. Soil Use and Management 29:162-174.

Powell, G.E., A.D. Ward, D.E. Mecklenburg, and A.D. Jayakaran. 2007. Two-stage channel systems: Part 1 , a practical approach for sizing agricultural ditches. Journal of Soil and Water Conservation 62(4):277-286.

Price, R.R. 2011. A general method to illustrate the different field efficiency gains of guidance systems. In Proceedings of the 2011 American Society of Agricultural and Biological Engineers Annual International Meeting, St. Joseph, MI: American Society of Agricultural and Biological Engineers.

Prokopy, L.S., K. Floress, D. Klotthor-Weinkauf, and A. Baumgart-Getz. 2008. Determinants of agricultural best management practice adoption: Evidence from the literature. Journal of Soil and Water Conservation 63(5):300-311, doi:10.2489/jswc.63.5.300.

Randall, G.W., and R.G. Hoeft. 1998. Placement methods for improved efficiency of $\mathrm{P}$ and $\mathrm{K}$ fertilizers: A review. Journal of Production Agriculture 1:70-79.

Roley, S.S., J.L. Tank, M.L. Stephen, L.T. Johnson, J.J. Beaulieu, and J.D. Witter. 2012. Floodplain restoration enhances denitrification and reachscale nitrogen removal in an agricultural stream. Ecological Applications 22:281-297.

Ross, J.A., M.E. Herbert, S.P. Sowa, J.R. Frankenberger, K.W. King, S.F. Christopher, J.L. Tank. J.G. Arnold, M.J. White, and H.Yen. 2016. A synthesis and comparative evaluation of factors influencing the effectiveness of drainage water management. Agricultural Water Management 178:366-376.

Runge, M., J.P. Fulton, T. Griffin, S. Virk, and A. Brooke. 2014. ANR-2217: Automatic Section Control Technology for Row Crop Planters. Auburn. AL: Alabama Cooperative Extension System, Auburn University.

Schoumans, O.F., W.J. Chardon, M.E. Bechmann, C. Gascuel-Odoux, G. Hofman, B. Kronvang, G.H. Rubaek, B. Ulen, and J.M. Doroiz. 2014. Mitigation options to reduce phosphorus losses form the agricultural sector and improve surface water quality: A review. Science of the Total Environment 498:1255-1266.

Sharpley, A.N., and S.J. Smith. 1994. Wheat tillage and water quality in the Southern Plains. Soil and Tillage Research 30:33-48.

Shipitalo, M.J., J.V. Bonta, E.A. Dayton, and L.B. Owens. 2010. Impact of grassed waterways and compost filter socks on the quality of surface runoff from corn fields. Journal of Environmental Quality 39:1009-1018.

Skaggs, W.R., N.R. Fausey, and R.O. Evans. 2012a. Drainage water management. Journal of Soil and Water Conservation 67(6):167A-172A, doi:10.2489/jswc.67.6.167A.

Skaggs, R.W., M.A. Youssef, and G.M. Chescheir. 2012b. DRAINMOD: Model use, calibration, and validation. Transactions of the American Society of Agricultural and Biological Engineers 55:1509-1522

Smith, D.R., K.W. King, L. Johnson, W. Francesconi, P. Richards, D. Baker, and A.N. Sharpley. 2015b. Surface runoff and tile drainage transport of phosphorus in the midwestern United States. Journal of Environmental Quality 44:495-502.

Smith, D.R., K.W. King, and M.R. Williams. 2015a. What is causing the harmful algal blooms in Lake Erie? Journal of Soil and Water Conservation 70(2):27A-29A, doi:10.2489/jswc.70.2.27A.

Smith, D.R., and S.J. Livingston. 2013. Managing farmed closed depressional areas using blind inlets to minimize phosphorus and nitrogen losses. Soil Use and Management 29:94-102.

Strock, J.S., P.M. Porter, and M.P. Russelle. 2004. Cover cropping to reduce nitrate loss through subsurface drainage in the northern US Corn Belt. Journal of Environmental Quality 33:1010-1016

USDA NRCS (Natural Resources Conservation Service). 2016. National Conservation Practice Standards. Washington, DC: USDA Natural Resources Conservation Service. http://www. nrcs.usda.gov/wps/portal/nrcs/detail/national/ technical/?cid=NRCSDEV11 001020 .

USDA NRCS. 2017. Soil Health Management. Washington, DC: USDA Natural Resources Conservation Service. https://www.nrcs.usda. gov/wps/portal/nrcs/main/soils/health/mgnt/.

Watts, D.B., and W.A. Dick. 2014. Sustainable uses of FGD gypsum in agricultural systems: Introduction. Journal of Environmental Quality 43:246-252.

Wilson, R.S., G. Howard, and E.A. Burnett. 2014. Improving nutrient management practices in agriculture: The role of risk-based beliefs in understanding farmers' attitudes toward taking additional action. Water Resources Research 50:6735-6746, doi:10.1002/2013WR015200. 